\title{
Conceptualizing the relationship between Spiritual and Entrepreneurial Orientation in developing sustainable enterprises
}

\section{Eshani Wickramasekera}

Sri Jayewardenepura University, Sri Lanka

\section{I.K. Peiris}

Open Polytechnic of New Zealand, New Zealand

\section{R. Ulluwishewa}

Sri Jayewardenepura University, Sri Lanka

\begin{abstract}
Entrepreneurship is considered a critical element that promotes the development of an economy and the society of a country. At the organizational level, the Entrepreneurial Orientation (EO) of decision-makers is recognized as a key driver in the entrepreneurship literature that propels firms to act 'autonomously', 'innovate', 'take risks', and be 'proactive' relative to marketplace opportunities. However, the current EO literature is evolving and has not explored its impact on developing sustainable operations. This paper intends to bridge this gap by introducing a concept of Spiritual Orientation (SO) playing the role of a mediator to explain the association between EO and sustainable operations. We argue that spirituality fortifies entrepreneurs' commitment to developing sustainable business entities, by empowering firms to be adaptable and creating a pro-social business model with a sense of interconnection with the community and natural ecosystem. Thus, it is important to understand the spiritual development of entrepreneurs, because it leads entrepreneurs to exhibit fairness, kindness, and improved awareness of other people's needs and thereby be sensitive to the alterations in the natural
\end{abstract}

\section{Corresponding Author:}

Eshani Wickramasekera, Sri Jayewardenepura University, Sri Lanka; Email: eshwik@gmail.com 
ecosystem. This paper argues that Spiritual Orientation leads entrepreneurs to exercise greater 'autonomy' as a result of seeing the interconnectedness of their actions. A spiritually oriented entrepreneur would place emphasis on the ethics, principles, virtues, values, and be sensitive to emotions, which will lead to taking proactive actions. As such, spirituality elucidates how business visionaries continue despite challenging situations by expanding their ideas of future-oriented sensemaking. This paper theorizes how a spiritually driven EO will lead to sustainable business ventures that focus on people, profit, and the planet. We assert that entrepreneurs must develop the spiritual maturity to create the right balance of EO dimensions, thus leading to creating sustainable organizations.

\section{Keywords:}

Entrepreneurship, Entrepreneurial Orientation, Spirituality, Spiritual Orientation, Sustainability, Triple Bottom line

\section{Introduction}

A considerable body of Entrepreneurial Orientation (EO) literature has revealed what it entails to be entrepreneurial at the organizational level and conceptualized as the manifestation of entrepreneurship as an organizational attribute (Covin \& Wales, 2019). The burgeoning scholarly interest in this field suggests that entrepreneurial organizations outperform their more conservatively controlled peers in general (Anderson, Kreiser, Kuratko, Hornsby, \& Eshima, 2015; Rauch, Wiklund, Lumpkin, \& Frese, 2009). As such, the indication solidly implies that EO continues to be a vibrant research topic in explaining firm-level performance (Covin \& Wales, 2019). However, to date, the EO research has narrowly concentrated on the ability of the EO-performance connection (Rauch et al., 2009). For example, EO literature primarily focused on applying dependent variables that reflect the economic performance of a firm such as, firm growth, profitability, innovativeness, and marketing orientation, rather than using a wholistic performance measure that includes social and environmental performance (Wales, Gupta, \& Mousa, 2011). There is hardly any research in the EO literature that explores the effect of EO on outcomes such as sustainability (Mullens, 2018). The antecedents of investments in sustainability with a link to EO remain poorly developed and understood (Dana, 2009; Hahn, Pinkse, Preuss, \& Figge, 2015). 
Furthermore, when it comes to moderation and mediator variables of EO, the focus has been on the networks, environmental dynamism, CEO tenure, knowledge-based resources, organizational learning, strategy, and structural organicity (Wales et al., 2011). Although there is an increasing interest among entrepreneurship scholars concerning the role of spirituality in entrepreneurial cognition (Dana, 2009; Ganzin, Islam, \& Suddaby, 2020; Mauksch, 2017), the EO literature has not given any attention to this important area with its moderator or a mediator effects on the firm performance.

The purpose of the paper is not to question the ontological assumptions of the EO construct, rather develop a robust conceptual framework to explore the EOperformance to understand the full effect of the EO contract and offer an explanation as to how spirituality could enhance this EO-performance relationship. Furthermore, we assert that the spiritual maturity of an entrepreneurial team acts as an antecedent variable that effects EO dimensions. Its impact on the EO seems to decide the long-term sustainability of the firm and its capacity to adjust to challenging situations.

This paper is divided into three sections: literature review, discussion, and conclusion. The literature section will cover significant research in the fields of EO and spirituality, while the discussion section will focus on developing an integrative framework to illustrate the EO spiritual orientation-sustainabilityperformance relationship. The conclusion section provides a summary of the paper and suggests future research directions.

\section{Literature Review}

Under this section, we discuss the relevant literature related to three different but connected domains: entrepreneurship and EO, spirituality, and sustainability. The relationship between entrepreneurship and EO is well established in the entrepreneurship and strategy literature. However, the proliferation of spirituality and sustainability into EO is still in its infancy and remains virtually unexplored in the empirical research.

\section{Entrepreneurship}

Entrepreneurship is an indispensable component of the economy and entrepreneurs are generally considered to be the ones who are encouraging the economic expansion by introducing innovations, novel concepts, and new ideas 
towards the production of improved and competitive products and services by giving millions of work openings (Zahra, 1999). As such, an entrepreneur creates wealth for individuals and societies (Raco \& Tanod, 2014). Schumpeter's (1934) induction of the entrepreneur as an individual who establishes brand new combinations and waves of innovative destruction along with reconstruction, paved the path in creating a separate domain for entrepreneurship research (Meyer, Heidi, \& Meeks, 2002). Kirzner (1973) incorporated a precise sense for 'entrepreneurship', recognizing it as the 'alertness' towards new opportunities, and also asserted that entrepreneurship is a series of innovative acts following on from the identification of such an opportunity (Koppl \& Minniti, 2003). Entrepreneurship is a broad concept. Scholars have established several definitions of entrepreneurship during the last 200 years of entrepreneurship studies, without sticking to any one of them (Hitt, Ireland, Camp, \& Sexton, 2002; Morris, Kuratko, \& Covin, 2008). The absence of a clear definition has hindered the creation of a new conceptual framework in the subject of entrepreneurship (Shane \& Venkataraman, 2000). Morris created the following definition of the concept of entrepreneurship, which is used in this work (Morris, 1998, p. 16):

"Entrepreneurship is the process through which individuals and teams create value by bringing together unique packages of resource inputs to exploit opportunities in the environment. It can occur in any organizational context and results in a variety of possible outcomes, including new ventures, products, services, processes, markets, and technologies".

This interpretation acknowledges the importance of the entrepreneur or entrepreneurial team, while still emphasizing the process view that capitalizes on opportunities. It also defines specific inputs and outputs that will lead to the production of value (Morris 1998). Entrepreneurial firms, according to Miller (1983), would be those who pursue innovation, proactively penetrate new markets, and embrace a certain amount of strategic and financial risk in search of new opportunities. Using Miller (1983) as a foundation, I proposed that organizations had two distinct strategic behavioural proclivities: conservative as well as entrepreneurial. Innovativeness, proactiveness, and risk-taking characterize the entrepreneurial end of the spectrum. As a result, scholars developed the concept of 'Entrepreneurial Orientation,' a firm-level strategic orientation regarding entrepreneurship (Lumpkin \& Dess, 1996). EO is largely regarded as a foundational idea in the literature on firm-level entrepreneurship 
(Wales et al., 2011). The essential act of entrepreneurship is a new entry. That is, new entry explains what entrepreneurship consists of, and entrepreneurial orientation describes how a new entry is undertaken (Lumpkin \& Dess, 1996, p. 136).

\section{Entrepreneurial Orientation}

In the realm of entrepreneurship, EO as well as entrepreneurship are connected but distinct conceptualizations that have gotten a lot of empirical and conceptual attention in the past decade (Covin \& Wales, 2012). A firm's EO refers to the entrepreneurial processes, to be specific how the business enterprise has undertaken the strategies, practices, and decision-making styles utilized towards new entry (Walter, Auer, \& Ritter, 2006). As it's an organizational level construct (Wales et al., 2011) and a solid indicator of the firm's execution, much remains to explore in relation to the conditions and factors that nurture it (Pittino, Visintin, \& Lauto, 2017).

The EO phenomenon has indeed been studied theoretically and empirically for even more than 30 years, and the notion is continually evolving (Covin \& Wales, 2019). Risk-taking, innovativeness, as well as proactiveness have all been used to operationalize EO as a unidimensional concept to explain how 'being entrepreneurial' manifests in businesses. These components moderate the relationship between outside variables such as social and cultural, economic, political, legitimate variables (Lee \& Peterson, 2000).

Rauch et al. (2009) contend that the fundamental dimensions of EO are regularly exceedingly intercorrelated with one another, which directs to a combination of these measurements into a single measure. Within the EO literature, there is no clear agreement as to how the EO factors are developed further. On the one hand, Covin and Slevin (1989) contend the EO develops as a unidimensional concept, which focuses on what is common among entrepreneurial organizations, whereas, on the other hand, Lumpkin and Dess (1996; 2001) are of the view that conceptualization focused on how entrepreneurial organizations can be distinct.

Concurring to the initial definition suggested by Miller (1983) and afterward created by Covin and Slevin (1989), EO shows through the concurrent nearness of three measurements, two of which are behavioral innovativeness and proactiveness and one is attitudinal risk-taking. Particularly, as per Covin and 
Slevin (1989), innovativeness is the tendency to bolster imaginative forms that will result in modern items, administrations, or innovations; proactiveness reflects demeanors toward the ceaseless interest of new openings, and chancetaking alludes to the eagerness to form ventures and asset commitments with uncertain returns.

Further expanding the three dimensions of EO, Lumpkin and Dess (1996), proposed two extra components, i.e., competitive aggressiveness and autonomy. Thus, the five EO dimensions construct are: autonomy, risk-taking, innovativeness, competitive aggressiveness, and proactiveness.

\section{The dimensions of $\mathrm{EO}$}

Innovativeness highlights an organization's propensity to lock in and back modern thoughts, experimentation, oddity, and inventive forms that will generate unused items, administrations, or mechanical forms, and it moreover speaks to a fundamental eagerness to withdraw from existing innovations and wander past the current state-of-the-art solutions (Lumpkin \& Dess, 1996). Innovativeness according to Covin and Slevin (1989) supports innovative ideas, novelty, experimentation, and the inventive process that seeks new solutions.

Autonomy is the ability and willingness to be self-directed in the pursuit of opportunities. It refers to an individual's or a team's independent activity in bringing forth an idea or a vision and pursuing it through to completion. Entrepreneurship has prospered since autonomous disapproved individuals have chosen to take off secure positions, in arranging to seek after novel thoughts or wander into modern markets. It is essential to facilitate the freedom to practice creativity along with champion promising ideas within an organization for entrepreneurship to result in (Covin \& Slevin, 1989).

Competitive Aggressiveness refers to an organization's propensity to directly and intensely challenge its competitors to accomplish market entry or improve market position, to outperform the industry rivals (Lumpkin \& Dess, 1996) responsively, with head-to-head confrontation moreover reflecting an eagerness to be unusual instead of depending on conventional strategies of competing. Cases of this and other shapes of competitive aggressiveness accessible to new participants incorporate embracing novel strategies to challenge industry pioneers (Cooper, Willard, \& Woo, 1986) which captures the unmistakable thought of "beating competitors to the punch" (Miller, 1983). 
Risk-taking is defined as committing considerable resources towards opportunities that have a reasonable risk of failing (Covin \& Slevin, 1989). Entrepreneurial enterprises, according to Lumpkin and Dess (1996), are frequently characterized by risk-taking behaviors, such as bringing about overwhelming obligations or making noteworthy asset commitments to get higher returns. Entrepreneurs from cultures that support risk-taking will receive the most out of decisions facing risks (Lumpkin \& Dess, 1996).

Proactiveness is significant to an EO since it is concerned with the execution to organize the enterprise. Proactive people do what is fundamental to bring their concepts to fulfillment and pick up an advantage by being the primary to capitalize on new businesses (Lumpkin \& Dess, 1996). Societies that emphasize entrepreneurial activity by empowering business people to seek after and expect openings and to take part in new or developing markets are characterized as proactive.

Table 1 outlines the definitions related to each dimension of EO. Covin, Green, and Slevin (2006, p. 57) present the subsequent definition of EO as "a strategic construct whose conceptual domain includes certain firm-level outcomes and management-related preferences, beliefs, and behaviours as expressed among a firm's top-level managers." This definition indicates both behavioral and attitudinal components within a single latent construct.

Table 1: the dimensions of Entrepreneurial Orientation and definitions

\begin{tabular}{ll}
\hline Dimension & Definition \\
\hline Innovativeness & $\begin{array}{l}\text { Predisposition to innovation and creativity through the } \\
\text { introduction of services and products, and also technological } \\
\text { leadership through R\&D in new procedures }\end{array}$ \\
\hline Autonomy & $\begin{array}{l}\text { Independent action is commenced by entrepreneurial leaders } \\
\text { or teams directed at creating a new venture and seeing it to } \\
\text { operate }\end{array}$ \\
\hline Competitive & The intensity of a firm's effort to outperform its competitors \\
aggressiveness & $\begin{array}{l}\text { Taking bold action by venturing into the unknown, borrowing } \\
\text { heavily, and/or committing significant resources to ventures } \\
\text { in uncertain environments }\end{array}$ \\
\hline Risk-Taking & $\begin{array}{l}\text { A forward-thinking, opportunity-seeking mindset defined by } \\
\text { developing new products and services ahead of the } \\
\text { competition and anticipating future market demand }\end{array}$ \\
\hline
\end{tabular}


Source: Rauch, et al., (2009, p. 763)

As such, it highlights that continual engagement in a certain behaviour reinforces the fundamental attitude (Anderson et al., 2015). This observation is important for two reasons, first, the attitudinal aspect of EO has not been given a sufficient level of attention in the EO literature as an antecedent variable. Second, it brings back the entrepreneurial cognition into EO dialogue, which can strengthen the relationship between attitudes and behaviour. Lumpkin and Dess (1996) suggest that a firm's strategic orientation was grounded in the values of its entrepreneur.

As per Neisser (1967), cognitions are processes by which sensory input is changed, decreased, elaborated, stored, improved, and utilized. These cognitive processes are deeply embedded in complex social contexts and influenced by one's values and deep beliefs. According to Krueger (2007), perceptions are guided by deep belief systems (deeply held strong assumptions), which in turn shape and influence one's knowledge content. Krueger $(2007$, p. 124) put this in the context of entrepreneurship and states:

- Behind the entrepreneurial actions are the entrepreneurial intentions

- Behind the entrepreneurial intentions are the known entrepreneurial attitudes

- Behind the entrepreneurial attitudes are the deep cognitive structures

- Behind the deep cognitive structures are the deep beliefs

Deep beliefs are driven by a sense of purpose. Spirituality offers a sense of purpose, a meaningful life, interconnection, and civic consciousness (Qureshi, Mukhtar, \& Saeed, 2017). It has been found that Spirituality plays a role in entrepreneurs' commitment to managing their entrepreneurial functions by progressing their efficiency, empowering adaptability, and innovativeness (Agbim, Oriarewo, \& Ijie, 2013). Although there has been an escalation in the research on the effect of spirituality on entrepreneurial behaviour (Qureshi et al., 2017), there are no clear theoretical or empirical literature themes emerging in the context of EO literature and how it affects EO and EO-performance interlink.

\section{Spirituality}

Spirituality is too complex to be defined in a single way. Spirituality is a multifaceted and cross-cultural notion. As such, it's a complex term with 
multifarious explanation which extends from inner wholeness connection to others (Gibbons, 2000). However, most definitions share several common components, such as: rejoining to the inward self; a look for all-inclusive values that boosts the person over self-centered strivings; profound compassion with all living creatures; and, lastly, a desire to some way or another keep in touch with the source of life. In other words, spirituality is the exploration of the inner character, connectedness, and transcendence (Bouckaert \& Zsolnai, 2012). Schmidt-Wilk, Heaton and Steingard (2000) identified three streams of definitions in the literature. First are the ones who describe spirituality in the light of a personal inner experience, such as the basic feeling of being connected to one's own self, others, and also the whole universe. The notion of connectivity may be summed up in a single word (Mitroff \& Denton, 1999, p. 83). The literature on the second stream of definitions of spirituality focus on principles, virtues, ethics, values, emotions, wisdom, and intuition. The degree to which these qualities are expressed in the behaviors and policies of organizations expresses the degree to which there is spirituality in management (Dehler \& Welsh, 1994). The definitions of the third-stream focus on the relationship between a personal inner experience and its manifestations in outer behaviors, principles, and practices (Stephen, Porth, \& McCall, 1999). For example, Neal, Lichtenstein, and Banner, (1999) discuss "spiritual integration," as a process of learning to use one's core spiritual principles to key aspects of one's life and work.

Even though the notion of spirituality has been conceptualized in association with religions, it is also conceptualized independently of religious affiliations (Melé \& Fontrodona, 2017). Religion is generally referred to as an organized belief system (GÖÇEr \& ÖZĞAn, 2018), and religion is a form that spirituality takes into practice (Guillory, 2000). Spirituality is the state of being one with the spirit or developing ourselves into who we are. Which is also the only purpose of our lives as human beings (Ulluwishewa, 2016).

Singh \& Premarajan, (2007) conceptualize Spiritual Orientation (SO) as a selfperceived construct that has three key components: spiritual attitude, spiritual knowledge, and spiritual skills, that influence one's ability to derive meaning and purpose, from work and life. Spiritual attitude is about keeping a positive view, thinking beyond the apparent, and having a feeling of peace within. Spiritual knowledge is being close to self, understanding the needs of others, and knowing that everything is affected by everything else. Spiritual skill is the 
ability to practice spirituality well, the ability to live in the moment, and the ability to take responsibility (Singh \& Premarajan, 2007, pp. 10-11).

\section{Spirituality and entrepreneurship}

Spirituality is the acknowledgment of something greater than mind and life (Aurobindo, 1997). The intersection of spirituality and entrepreneurship holds a key to understanding how an entrepreneur's mindset works with the values and beliefs and how they impact business activities. More importantly how they impact the entrepreneurial process, such as the identification of opportunities, relationship with stakeholders, organizational culture, creation of new ventures, and growth of the firms (Balog, Baker, \& Walker, 2014; Ibrahim, Rue, McDougall, \& Greene, 1991). Spirituality, unlike religion, is considered as both individual and universal, created outside of traditional, organized religion, and as open-minded (King-Kauanui, Thomas, \& Waters, 2005; Mitroff, 2003). Spiritually oriented entrepreneurs are often capable of seeing the bigger picture and integrate social concerns with economic ones (King-Kauanui et al., 2005). They state that they have a 'calling' to make a difference through service to others and, in doing so, derives meaning and purpose in their lives (Silk, 2007). Balog, Baker and Walker (2014), after reviewing nearly 30 empirical articles connected to religion and spirituality in entrepreneurship, reported the following key outcomes:

- Entrepreneurial motives and attitudes are influenced by religion and spirituality.

- Religion and spirituality appear to have an impact on entrepreneurs' ethical business behaviour by offering a solid frame of reference for decision-making that is bolstered by the qualities of honesty and integrity.

- Religious and spiritual values have a substantial impact on entrepreneurs' happiness, health, joy, productivity, and coping skills, as well as a considerable reduction in stress and anxiety.

- May have a role in the link between society, religion, and business by supporting and enhancing (or decreasing) the atmosphere for entrepreneurship.

- $\quad$ Research on the relationship between spiritual and religious values and organizational success must be prioritized in the future.

They did, however, draw attention to the lack of solid theoretical underpinnings in this field, as none of the studies they looked at were based on a theoretical 
framework that would allow for sound hypothesis construction. To gain a better understanding of the relative significance of spiritual values in business, and entrepreneurial activities, they suggested using EO construct to legitimize the spirituality-entrepreneurship link and investigate how the values of an entrepreneur can impact the communities the business serves and relationships with other stakeholders.

The role of spirituality in the workplace is a relatively recent field of research that focuses on the impact of Spiritual Orientation (SO) (i.e. spirituality within an individual) on performance (Parente, Eltarabishy, Vesci, \& Botti, 2018). Spirituality triggers an entrepreneur to launch a firm (Raco \& Tanod, 2014), make entrepreneurial actions meaningful (Pavlovich \& Corner, 2014), and make better decisions (Nolan, 2005). Spirituality strengthens the commitment of entrepreneurs to advance their businesses, to help them deal with stressful situations, to sharpen the vision of their businesses, to stride their efficiency, and to empower flexibility and imagination to motivate them in keeping their business values (Agbim et al., 2013). Spirituality may also help entrepreneurs find purpose in their work, increase their satisfaction, and increase their loyalty to their company.

Based on the literature related to spirituality given by various authors, Singh and Premarajan (2007) identified six dimensions that exhibit the spiritual orientation of an individual: 1) Service towards humankind (caring, hopeful, kind, compassionate, and empathetic towards others; walking in the neighbor's shoes); 2) Feeling of inner peace and calm (happy with the self, environment, work, and others; no complaint with life, feeling positive about life); 3) Being vision and value-led (It is reaching beyond, or having a sense that things could be better); 4) Inter-connectedness (everything is a part and expression of oneness, interconnected with everything else); 5) Respect for others (personal privacy, physical space, and belongingness, religion, gender, lifestyle)) 6) Selfawareness (knowing self, what I believe in, What will I fight for?). These dimensions could provide a deeper meaning as to how and why entrepreneurs and their organizations act towards achieving a higher purpose.

Drawing on these dimensions Table 2 depicts how SO orientation could act as an explanatory variable to understand how EO could be influenced towards achieving a spirituality-based organization that goes beyond successful business operations. 
Table 2 Linking EO dimensions to Spiritual Orientation.

\begin{tabular}{|c|c|c|}
\hline Dimension & EO & SO \\
\hline Innovativeness & $\begin{array}{l}\text { Predisposition to } \\
\text { innovation and } \\
\text { creativity through } \\
\text { the launch of } \\
\text { services and } \\
\text { products, as well } \\
\text { as superior } \\
\text { technology } \\
\text { through R\&D in } \\
\text { new processes }\end{array}$ & $\begin{array}{l}\text { Being vision and value-led (it is } \\
\text { reaching beyond or having a sense that } \\
\text { things could be better), by seeing the } \\
\text { bigger picture and integrate social } \\
\text { concerns with economic ones. }\end{array}$ \\
\hline Autonomy & $\begin{array}{l}\text { Entrepreneurial } \\
\text { leaders or teams } \\
\text { take independent } \\
\text { action in order to } \\
\text { launch a new } \\
\text { enterprise and see } \\
\text { it through to } \\
\text { completion }\end{array}$ & $\begin{array}{l}\text { Self-awareness (knowing self, what I } \\
\text { believe in, What will I fight for?) leads } \\
\text { to higher autonomy and taking } \\
\text { responsibility for one's actions. }\end{array}$ \\
\hline $\begin{array}{l}\text { Competitive } \\
\text { aggressiveness }\end{array}$ & $\begin{array}{l}\text { The intensity of a } \\
\text { firm's effort to } \\
\text { outperform rivals }\end{array}$ & $\begin{array}{l}\text { Harness the value of inter- } \\
\text { connectedness (everything is a part and } \\
\text { expression of oneness, interconnected } \\
\text { with everything else) to outperform } \\
\text { others by building responsible business } \\
\text { behavior that promotes the virtues of } \\
\text { honesty and integrity. }\end{array}$ \\
\hline Risk-Taking & $\begin{array}{l}\text { Taking risks by } \\
\text { traveling into the } \\
\text { unknown, taking } \\
\text { on considerable } \\
\text { debt, and/or } \\
\text { investing } \\
\text { considerable } \\
\text { resources to } \\
\text { initiatives in risky } \\
\text { circumstances }\end{array}$ & $\begin{array}{l}\text { Taking meaningful actions while } \\
\text { respecting others (personal privacy, } \\
\text { physical space, and belongingness, } \\
\text { religion, gender, lifestyle, and } \\
\text { environment) }\end{array}$ \\
\hline Proactiveness & $\begin{array}{l}\text { A forward- } \\
\text { thinking, } \\
\text { opportunity- } \\
\text { seeking mindset } \\
\text { defined by } \\
\text { developing new } \\
\text { products and }\end{array}$ & $\begin{array}{l}\text { Service towards humankind (caring, } \\
\text { hopeful, kind, compassionate, and } \\
\text { empathetic towards others; walking in } \\
\text { the neighbor's shoes) and feeling of } \\
\text { inner peace and calm (happy with self, } \\
\text { environment, work, and others; no } \\
\text { complaint with life, feeling positive }\end{array}$ \\
\hline
\end{tabular}




\begin{tabular}{lll}
\hline Dimension & EO & SO \\
\hline & $\begin{array}{l}\text { services ahead of } \\
\text { the competition } \\
\text { and anticipating } \\
\text { future demand }\end{array}$ & $\begin{array}{l}\text { about life); provide impetus to forward- } \\
\text { thinking. }\end{array}$ \\
&
\end{tabular}

Source: Author compiled

Spirituality and Sustainability are more related than they seem, and they both engender success at both individual and organizational levels (Beehner, 2019). Spirit provides purpose to the mind that allows the body to act. These three components the body, mind and spirit are interconnected and essential for sustainability. One can sense nature and society through rational and logical analysis and scientific observations, yet a deeper sense can be gained physically and mentally (Ikerd, 2000). It is noticed that external changes that one brings about towards achieving sustainability are ineffective without one's inner change. When materialistic values such as money, material possessions, recognition, power, and social status are held at the center of focus unsustainable behaviors result (Ulluwishewa, 2018).

\section{Sustainability and performance}

As per the Brundtland Commission (1987), sustainability is defined as development that meets the needs of the present without compromising the ability of future generations to meet their own needs. Kraus, Niemand, Halberstadt, Shaw, \& Syrjä (2017), posit, in contrast to firms that are exclusively oriented towards profitability, a socially responsible firm is one that, in addition to making a profit, strives to comply with applicable laws and behaves ethically and responsibly. Sustainability literature refers to three performance measures: economic, social, and environmental (Mullens, 2018) and hence the term 'triple-bottom-line'(TBL), suggesting that the people, profit, and planet are interrelated and interact with each other in different ways (Elkington, 1997). As such, business sustainability consists of creating both financial value for shareholders and non-financial value for other stakeholders (including business partners, employees, suppliers, customers, government, society at large, etc.) (Rezaee, 2016). Successful pursuit of proactive sustainable strategies that focus on the three performance measures requires both motivation and attitude to deploy organizational capabilities to achieve sustainable goals (Sharma \& Sharma, 2011). Spiller (2000) suggests an "ethical scorecard" for performance measurement, arguing that corporations may attain a triple bottom 
line of environmental, social, and financial performance. Spiller (2000) listed four Aristotelian qualities (honesty, fairness, caring, and courage) as principles that ethical investors look for in enterprises, as well as ten critical business practices for six different stakeholder groups. Spiller argues, based on international data, that corporations can perform well by doing good at no expense.

The entrepreneurship literature is slowly evolving from economically oriented, profit-making venture creation to being future-focused balancing efforts in making contributions to produce economic gains, social equity, cultural preservation, and as well as environmental quality (Majid \& Koe, 2012). Dixon and Clifford (2007), found a strong link between the entrepreneurial flair of the CEO enabling the pursuit of environmental, social, and economic goals. Gu, Wang, Hua, and Liu (2021) found a close relationship between entrepreneurship and TBL of sustainable development. However still, there are only a few papers studying sustainable development from the perspective of entrepreneurship ( $\mathrm{Gu}$, Wang, Hua, \& Liu, 2021).

\section{Methodology}

\section{Towards a conceptual model}

To date the link between spirituality orientation, entrepreneurial orientation, and sustainable performance has not been explored in the entrepreneurship literature. However, based on the existing research, we posit that these three constructs can be integrated to provide a robust conceptual framework to study the sustainable performance of entrepreneurial ventures.

Although the EO literature has a plethora of studies looking at the effect of EO on performance, there is no clear agreement as to how the EO factors could be developed further (Covin \& Wales, 2019; Rauch et al., 2009). On the other hand, the link between TBL and EO is still in its infancy (Gu et al., 2021; Majid $\&$ Koe, 2012). Much is needed to understand how EO can effectively sustain the TBL in the long run. As such, we must focus on the underlying tendencies that lead to entrepreneurial behavior, such as, attitudes, beliefs, and values. These cognitive aspects have a strong link with spirituality (Schmidt-Wilk, Heaton, \& Steingard, 2000).

Spirituality ignites from inside, connected with one's work, others, and the universe. Spirituality results in intuition and creativity, honesty and trust, personal fulfillment along with a deeper commitment, and enhanced business 
performance moving away from personal benefits at the egocentric stage (Raco, Ohoitimur, \& Sobon, 2019). As a result, it can assist individuals in developing a more compelling and purposeful organizational vision, which can lead to more innovation. Spiritual principles can help to improve teamwork and employee loyalty to the company that promotes innovation. Spiritual orientation helps entrepreneurial organizations to see the bigger picture and the holistic effects of their actions. This leads to innovative actions and creating new products and services that enhance not only the profitability of the company but also contributing to positive social and environmental outcomes.

Entrepreneurs make a difference or create change for the well-being of society where spirituality fosters their intention for start-up ventures surpassing all mental frameworks (Judge \& Douglas, 2013). Entrepreneurs imagine new ways to create value and solve problems since they are driven by the importance of values and the purpose of entrepreneurs' activities. Meaning, purpose and values are also the key components of spirituality (Raco et al., 2019). A spiritually oriented entrepreneur will not seek for their benefit, but the wellbeing of others by thinking outside the box which will grow better and enjoy economic benefits (Raco et al., 2019). With the focus only on profit-making, modern businesses violate the integrity and diversity of natural ecosystems and the culture of local communities. To meet real human needs (social sustainability) and preserve nature (environmental sustainability) the economic actors must be driven by intrinsic motivation.

Entrepreneurs who have a spiritual underpinning will encourage pro-social businesses (Pavlovich \& Corner, 2014). It is the business approach that puts the community and people's interests before profit (Driver, 2012); create a sense of community (Agbim et al., 2013); understand interconnectedness (Karakas, 2010), and strategically apply spirituality in offering quality services for others (Raco, et al., 2019). A spiritual orientation provides a belief system (Pratt, 2000) where they can justify their conduct, a distinct identity or role within that system to encourage their actions, and a roadmap that provides a path to success.

Entrepreneurs cope with risk, doubt, and uncertainty by expanding past successes into the future (Cornelissen \& Clarke, 2010). Mitroff and Denton (1999) saw that spirituality reduces fear among individuals which will empower risk-taking. Entrepreneurship scholars state that spirituality facilitates a robust frame of reference for making decisions and influences responsible business conduct (Fernando \& Jackson, 2006) with a clear mind, creativity, and wisdom 
that will enable the economic system as a whole to indefinitely sustain its production.

Based on the existing literature related to the spirituality, we propose a conceptual model to capture the key roles played by spiritual orientation of the decision-makers. Primarily drawing on the work of Singh and Premarajan (2007), we posit that SO has many functions in the EO-TBL relationship. First, SO could function as a mediator variable in the EO-TBL relationship providing the fundamental basis for developing a sustainable business, grounded on a purpose-driven vision of serving humankind, harnessing the value of interconnectedness, and developing an organizational culture that embraces the sustainable approach to organizational performance.

Second, SO could act as an antecedent to EO dimensions, providing the valuebased grounding that is needed to effectively exhibit entrepreneurial behavior with a focus on sustainability. Third, SO could act as a mediator variable between the EO-TBL link. For example, when the organization has a strong value-based culture where spiritual values are embedded in the organizational system, entrepreneurial behavior will be guided by these values when making strategic moves, which in turn affect the three performance dimensions (economic, social, and environmental). We argue that EO alone cannot sustain the TBL. It needs a stronger foundation that goes beyond the materialistic view of organizational outcomes. Figure 1 depicts the link between the three constructs. 


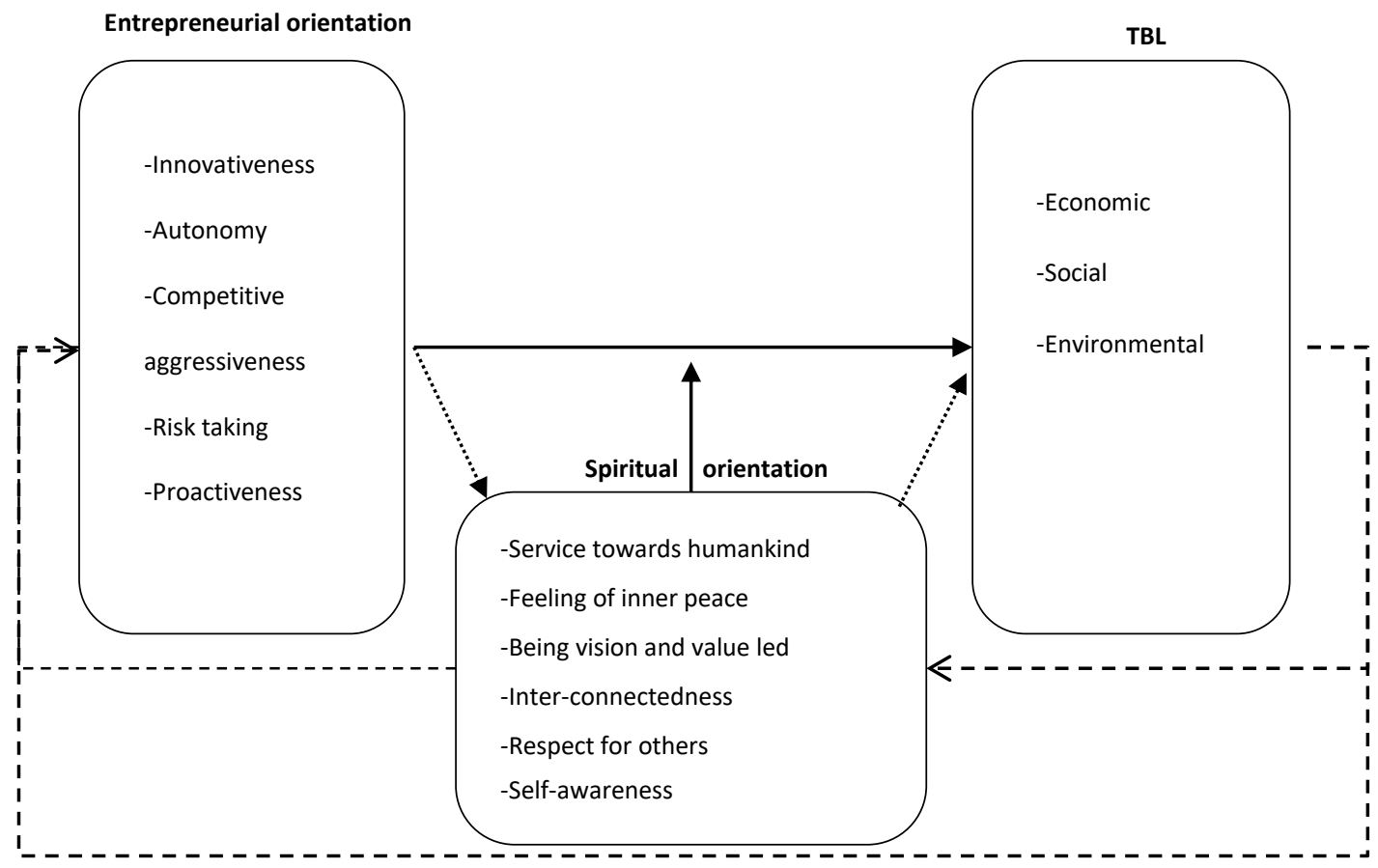

Figure 1: Conceptual framework

Source: Author compiled based on the literature review

According to Drucker (1985), spirituality is required for organizational, social, and economic development with ethical and improved teamwork. The meaning of work is to lead a common goal while addressing man's human goals such as happiness (Bouckaert \& Zsolnai, 2012). Sustainability is the protection, development, and maintenance of society, nature, economy, and individuals (Wiklund \& Shepherd, 2005). Entrepreneurs with strong spirituality-oriented leadership may operate their firms not only to make money - for themselves and others - but also to effectively benefit the community (Raco, et al., 2019).

Our conceptual paper offers a theoretically grounded model to operationalize a new link in the EO literature and we have opened several investigative possibilities to link the EO-SO-TBL relationship. Future research could empirically test these relationships in different contexts and see the longitudinal effects of EO-SO-TBL outcomes. Entrepreneurs must have the capability to develop the right balance between EO dimensions and the long-term sustainability of the firm. As a result, spirituality is required as a foundation for 
both corporate ethics and sustainability management in order to achieve the element of "people, profit, and planet."

\section{Conclusions}

Spiritual Orientation and EO go hand in hand in creating sustainable organizations. We discussed the literature related to SO and EO, along with the explanation of how they contribute to sustainable business efforts. Spiritually grounded entrepreneurs seek with their mutually supportive outward acts, for meaning, purpose, and happiness in the external world of business and the internal world of consciousness and conscience. Their internal reflections making sustainability and spirituality also mutually supportive. Finally, we have proposed a conceptual model to operationalize these relationships and highlighted the significance of empirically testing the EO-SO-TBL connection in a different context. We acknowledge that the theoretical underpinnings of entrepreneurship, spirituality and sustainability are constantly evolving. Our conceptual framework only offers the first cut to lay a robust foundation for future scholars to understand the theoretical boundaries of these domains and empirically test these constructs in different contexts. Our framework shows an integrative outcome of entrepreneurial actions and spiritual orientations; this could support the practitioners to incorporate spirituality into their organizations with a clear focus of developing sustainable organizations.

\section{Declaration of Conflicting Interests}

The authors declared no potential conflicts of interest with respect to the research, authorship, and publication of this article.

\section{Authors' Contributions}

EW participated in drafting the relevant literature and the findings towards developing the conceptual model. IP participated in developing the conceptual model and helped to draft the manuscript.RU helped in drafting the manuscript and also in developing the conceptual model.

\section{References}

Agbim, K. C., Oriarewo, G. O., \& Ijie, N. (2013). The relative importance of spirituality in entrepreneurship development among graduates of Nigerian Tertiary Institutions. International Journal of Business and Management Invention, 2(4), 25-35. 
Anderson, B. S., Kreiser, P. M., Kuratko, D. F., Hornsby, J. S., \& Eshima, Y. (2015). Reconceptualizing entrepreneurial orientation. Strategic Management Journal, $\quad 36(10), \quad$ 1579-1596. doi:https://doi.org/10.1002/smj.2298

Aurobindo, S. (1997). An introduction to true spirituality. Sri Aurobindo Society, Pondicherry, 13.

Balog, A. M., Baker, L. T., \& Walker, A. G. (2014). Religiosity and spirituality in entrepreneurship: a review and research agenda. Journal of Management, Spirituality \& Religion, 11(2), 159-186. doi:10.1080/14766086.2013.836127

Beehner, C. G. (2019). Spirituality, sustainability, and success Switzerland AG: Springer Nature

Bouckaert, L., \& Zsolnai, L. (2012). Spirituality and business: An interdisciplinary overview. Society and Economy, 34(3), 489-514.

Brundtland, G. H. (1987). Report of the World Commission on Environment and Development: Our common future, from one earth to one world. Retrieved from Oslo:

Cooper, A. C., Willard, G. E., \& Woo, C. Y. (1986). Strategies of high performing new and small firms: A reexamination of the niche concept. Journal of Business Venturing, 1(3), 247-260.

Cornelissen, J. P., \& Clarke, J. S. (2010). Imagining and rationalizing opportunities: Inductive reasoning and the creation and justification of new ventures. Academy of Management Review, 35, 539-555.

Covin, J. G., Green, K. M., \& Slevin, D. P. (2006). Strategic process effects on the entrepreneurial orientation - sales growth rate relationship. Entrepreneurship theory and practice, 30(1), 57-81.

Covin, J. G., \& Wales, W. J. (2012). The measurement of entrepreneurial orientation. Entrepreneurship theory and practice, 36(4), 677-702.

Covin, J. G., \& Wales, W. J. (2019). Crafting high-impact entrepreneurial orientation research: Some suggested guidelines. Entrepreneurship: Theory and Practice, 43(1), 3-18. Retrieved from https://link.gale.com/apps/doc/A570660750/GPS?u=otago\&sid=GPS\&xid=8 $281 \mathrm{ebac}$

Dana, L. P. (2009). Religion as an explanatory variable for entrepreneurship. International journal of entrepreneurship and innovation, 10(2), 87-99. doi:10.5367/000000009788161280

Dehler, G., \& Welsh, M. (1994). Spirituality and Organizational Transformation: Implications for the New Management Paradigm. Journal of Managerial Psychology, 17-26. 
Dixon, S. E., \& Clifford, A. (2007). Ecopreneurship-a new approach to managing the triple bottom line. Journal of Organizational Change Management.

Driver, M. (2012). An interview with Michael Porter: Social entrepreneurship and the transformation of capitalism. Academy of Management Learning \& Education, 11(3), 421-431.

Drucker, P. (1985). Innovation and entrepreneurship New York: Harper and Row.

Elkington, J. (1997). Cannibals with forks. The triple bottom line of 21st century, 73.

Fernando, M., \& Jackson, B. (2006). The influence of religion-based workplace spirituality on business leaders' decision-making: An inter-faith study. Journal of Management \& Organization, 12, 23-39.

Ganzin, M., Islam, G., \& Suddaby, R. (2020). Spirituality and entrepreneurship: The role of magical thinking in future-oriented sensemaking. Organization studies, 41(1), 77-102. doi:10.1177/0170840618819035

Gibbons, P. (2000). Spirituality at work: Definitions, measures, assumptions, and validity claims. Work and spirit: A reader of new spiritual paradigms for organizations. In: University of Scranton Press, Scranton, PA.

GÖÇEr, A., \& ÖZĞAn, H. (2018). Spirituality and ethics: A literature review. Ruhsallı ve Etik: Bir Alanyazın Taraması., 17, 58-65. doi: $10.21547 /$ jss. 452152

Gu, W., Wang, J., Hua, X., \& Liu, Z. (2021). Entrepreneurship and high-quality economic development: based on the triple bottom line of sustainable development. International entrepreneurship and management journal, 17(1), 1-27. doi:10.1007/s11365-020-00684-9

Guillory, W. A. (2000). The living organization: Spirituality in the workplace. In: Salt lake city, UT: Innovations International Inc.

Hahn, T., Pinkse, J., Preuss, L., \& Figge, F. (2015). Tensions in corporate sustainability: Towards an integrative framework. Journal of Business Ethics, 127(2), 297-316.

Hitt, M. A., Ireland, R. D., Camp, S. M., \& Sexton, D. L. (Eds.). (2002). Strategic entrepreneurship: Integrating entrepreneurial and strategic management perspectives. MA: Blackwell Publishing.

Ibrahim, N. A., Rue, L. W., McDougall, P. P., \& Greene, G. R. (1991). Characteristics and practices of "Christian-based" companies. Journal of Business Ethics, 10(2), 123-132. 
Ikerd, J. (Producer). (2000). Deep sustainability: The essentials. Retrieved from https://sites.google.com/site/sustainabilitydeep/

Judge, W. Q., \& Douglas, T. J. (2013). Entrepreneurship as a leap of faith. Journal of Management, Spirituality and Religion, 10(1), 37-65.

Karakas, F. (2010). Spirituality and performance in organizations: A literature review. Journal of Business Ethics, 94(1), 89-106.

King-Kauanui, S., Thomas, K. D., \& Waters, G. R. (2005). Entrepreneurship and spirituality: integration of spirituality into the workplace. Journal of Management, Spirituality \& Religion, 2(2), 255-274.

Kirzner, I. M. (1973). Competition and entrepreneurship. Chicago, IL: University of Chicago Press.

Koppl, R., \& Minniti, M. (Eds.). (2003). Market processes and entrepreneurial studies New York, NY: Springer Science.

Kraus, S., Niemand, T., Halberstadt, J., Shaw, E., \& Syrjä, P. (2017). Social entrepreneurship orientation: development of a measurement scale. International Journal of Entrepreneurial Behavior \& Research, 23(6), 977997.

Krueger Jr, N. F. (2007). What lies beneath? The experiential essence of entrepreneurial thinking. Entrepreneurship theory and practice, 31(1), 123138.

Lee, S. M., \& Peterson, S. J. (2000). Culture, entrepreneurial orientation, and global competitiveness. journal of World Business, 35(4), 401-416.

Lumpkin, G. T., \& Dess, G. G. (1996). Clarifying the entrepreneurial orientation construct and linking it to performance. Academy of Management Review, 21(1), 135-172.

Lumpkin, G. T., \& Dess, G. G. (2001). Linking two dimensions of entrepreneurial orientation to firm performance: The moderating role of environment and industry life cycle. Journal of Business Venturing, 16, 429251.

Majid, I. A., \& Koe, W.-L. (2012). Sustainable entrepreneurship (SE): A revised model based on triple bottom line (TBL). International Journal of Academic Research in Business and Social Sciences, 2(6), 293.

Mauksch, S. (2017). Managing the dance of enchantment: An ethnography of social entrepreneurship events. Organization, 24(2), 133-153.

Melé, D., \& Fontrodona, J. (2017). Christian ethics and spirituality in leading business organizations: Editorial introduction. Journal of Business Ethics, 145(4), 671-679. 
Meyer, G. D., Heidi, M. N., \& Meeks, M. D. (2002). Entrepreneurship and strategic management. In M. A. Hitt, R. Ireland, S. M. Camp, \& D. L. Sexton (Eds.), Strategic entrepreneurship: Creating a new mindset (pp. 19-44). Oxford: Blackwell Publishers.

Miller, D. (1983). The correlates of entrepreneurship in three types of firms Management Science, 29, 770-791.

Mitroff, I. I. (2003). Do not promote religion under the guise of spirituality. Organization, 10(2), 375-382.

Mitroff, I. I., \& Denton, E. A. (1999). A study of spirituality in the workplace. MIT Sloan Management Review, 40(4), 83.

Morris, M. H. (1998). Entrepreneurial intensity: Sustainable advantages for individuals, organizations and societies Westport, CT: Quorum.

Morris, M. H., Kuratko, D. H., \& Covin, J. G. (2008). Corporate entrepreneurship and innovation (2nd ed.). Ohio, USA Thomson Higher Education.

Mullens, D. (2018). Entrepreneurial orientation and sustainability initiatives in family firms. Journal of Global Responsibility, 9(2), 160-178. doi:10.1108/JGR-03-2017-0020

Neal, J. A., Lichtenstein, B. M., \& Banner, D. (1999). Spiritual perspectives on individual, organizational and societal transformation. Journal of Organizational Change Management, 175-186.

Neisserr, U. (1967). Cognitive psychology. New York: Appleton-CenturyCrafts.

Nolan, P. (2005). From first-person inquiry to radical social action. Action Research, 3(3): 297-312.

Parente, R., Eltarabishy, A., Vesci, M., \& Botti, A. (2018). The epistemology of humane entrepreneurship: Theory and proposal for future research agenda. Journal of Small Business Management, 56(sup1), 30-52. doi:10.1111/jsbm.12432

Pavlovich, K., \& Corner, P. D. (2014). Conscious enterprise emergence: Shared value creation through expanded conscious awareness. Journal of Business Ethics, 121(3), 341-351.

Pittino, D., Visintin, F., \& Lauto, G. (2017). A configurational analysis of the antecedents of entrepreneurial orientation. European Management Journal, 35(2), 224-237.

Pratt, M. G. (2000). Building an ideological fortress: The role of spirituality, encapsulation and sensemaking. Studies in Cultures, Organizations and Societies, 6(1), 35-69. 
Qureshi, S., Mukhtar, M. M., \& Saeed, M. A. (2017). The impact of spirituality on individual entrepreneurial orientation: An empirical study of Pakistani university students. Global management journal for academic \& corporate studies, 7(2), 159-165.

Raco, J., Ohoitimur, J., \& Sobon, K. (2019). Spirituality: The power of entrepreneurship. EMAJ: Emerging Markets Journal, 9(1), 28-35. doi:10.5195/emaj.2019.161

Raco, J., \& Tanod, R. H. (2014). The phenomenological method in entrepreneurship. International Journal of Entrepreneurship and Small Business, 22(3), 276-285.

Rauch, A., Wiklund, J., Lumpkin, G. T., \& Frese, M. (2009). Entrepreneurial orientation and business performance: An assessment of past research and suggestions for the future Entrepreneurship theory and practice, May, 761787. doi:10.1111/j.1540-6520.2009.00308.x

Rezaee, Z. (2016). Business sustainability research: A theoretical and integrated perspective. Journal of Accounting literature, 36, 48-64.

Schmidt-Wilk, J., Heaton, D. P., \& Steingard, D. (2000). Higher education for higher consciousness: Maharishi University of Management as a model for spirituality in management education. Journal of management education, 24(5), 580-611.

Schumpeter, J. A. (1934). The theory of economic development Cambridge, MA: Harvard University Press

Shane, S., \& Venkataraman, S. (2000). The promise of entrepreneurship as a field of research. Academy of Management Review, 25(1), 217-226.

Sharma, P., \& Sharma, S. (2011). Drivers of proactive environmental strategy in family firms. Business Ethics Quarterly, 309-334.

Silk, M. (2007). Defining religious pluralism in America: A regional analysis. The ANNALS of the American academy of political and social science, 612(1), 62-81.

Singh, T., \& Premarajan, R. (2007). Individual spiritual orientation at work: a conceptualization and measure. IIM Bangalore Research Paper(264).

Spiller, R. (2000). Ethical business and investment: A model for business and society. Journal of Business Ethics, 27(1/2), 149-160. doi:10.1023/A:1006445915026

Stephen , J., Porth, J., \& McCall, T. (1999). Spiritual themes of the "learning organization". Journal of Organizational Change Management. 
Ulluwishewa, R. (2016). Spirituality, sustainability and happiness: A quantumneuroscientific perspective. In Spirituality and Sustainability (pp. 155-168): Springer.

Ulluwishewa, R. (2018). Education in human values: Planting the seed of sustainability in young minds. In S. Dhiman \& J. Marques (Eds.), Handbook of engaged sustainability. AG: Springer Intertional Publishing

Wales, W. J., Gupta, V. K., \& Mousa, F.-T. (2011). Empirical research on entrepreneurial orientation : An assessment and suggestions for future research International Small Business Journal, 1-27. doi:10.1177/0266242611418261

Walter, A., Auer, M., \& Ritter, T. (2006). The impact of network capabilities and entrepreneurial orientation on university spin-off performance. Journal of Business Venturing, 21, 541-567.

Wiklund, J., \& Shepherd, D. (2005). Entrepreneurial orientation and small business performance: A configurational approach Journal of business venturing 20, 71-91. doi:10.1016/j.jbusvent.2004.01.001

Zahra, S. A. (1999). The changing rules of global competitiveness in the $21 \mathrm{st}$ century. Academy of management perspectives, 13(1), 36-42. 